\title{
ХРИСТИЯНСЬКІ РЕЛІГІЙНІ МОДЕЛІ ТАРАСА ШЕВЧЕНКА В ДИСКУРСИВНОМУ ПОЛІ ІВАНА ОГІЕНКА
}

\begin{abstract}
У статті проаналізовано релігійність Тараса Шевченка крізь призму досліджень Івана Огієнка (митрополита Іларіона). Основний акиент зроблено на чинниках, щзо формували християнське світосприйняття письменника; досліджено значення християнських святинь, які потлумачено з погляду релігії, фольклору та самого поета; простежено навчальну, моральну та виховну функиії Шевченкових творів.
\end{abstract}

Ключові слова: релігійність, християнське світосприйняття, ичерковний канон, стиль, текст, контекст.

В статье проанализировано религиозность Тараса Шевченка сквозь призму исследований Ивана Огиенка (митрополита Иллариона). Основной акиент сделан на факторах, которые формировали христианское мировосприятие писателя; исследовано значение христианских святынь, которые анализируются $c$ точки зрения религии, фольклора и самого поэта; прослежено учебную, моральную и воспитательную функиии призведений Т. Шевченка.

Ключевые слова: религиозность, христианское мировоззрение, иерковный канон, стиль, текст, контекст.

The article analyzes the religiousness of Taras Shevchenko through the lens of research of Ivan Ohienko (metropolitan Ilarion). The main emphasis is on factors that formed the Christian worldview of the writer; the value of Christian objects of worship are investigated from the point of view of religion, folklore and the poet; educational, moral and educational functions are analyzed in Shevchenko's works.

Key words: religiousness, Christian worldview, canon of the church, style, text, context.

Одним із важливих аспектів дослідження творчості Тараса Шевченка є його релігійність. Адже твори митця насичені зверненнями до Бога, пронизані християнським світосприйняттям та зацікавленням церковними темами. Водночас, як зазначає Д. Степовик, «Шевченкова творчість не дає однозначної відповіді, як він ставився до Бога, до церкви і до релігії загалом» [Степовик 2013: 18]. Таким чином, оцінки релігійності Т. Шевченка варіюють від образу упокореного християнина до суперечності його зовнішньої набожності «епікурейському» способу життя, й аж до оцінок постаті Т. Шевченка як «богохульного поета» російською православною церквою та як «атеїста» совєтською ідеологією. 
Отже, спробуємо дослідити релігійність письменника, скориставшись оцінкою його творів одного із найвідоміших українських церковних i громадських діячів, істориків церкви й освітян Митрополита Іларіона (в миру Іван Іванович Огієнко). Закцентуємо увагу на монографічному дослідженні, яке дістало назву «Релігійність Тараса Шевченка» (1964).

На перших сторінках дослідження автор розкриває завдання, які поставив перед собою: «Завдання моє аж надто важке, але необхідне. Привселюдно 9 липня 1961 року у Вінніпегу на парламентській площі, у присутності може яких 50 тисяч народу, я поблагословив пам'ятника Т. Шевченкові... Тепер хочу ніби висповідати Шевченка і дати йому повне відпущення вільних $і$ невільних гріхів, як особа духовна. Бо ж Шевченко став душею всього украӥнського народу!» [Огієнко 2003: 174].

Обрану проблему митрополит Іларіон вважав для себе глибоко важливою i принциповою. Адже його багаторічний досвід як професора та вченого, й особливо його відповідний духовний сан «вимагали у цій тонкій справі повної об’єктивності та глибокої обдуманості» [Огієнко 2003: 29]. Тому в монографічному дослідженні зроблено спробу з'ясувати витоки релігійності Тараса Шевченка, його глибокої побожності, всебічно проаналізувати ознаки стилю, окреслити контекст, у якому поет розглядає християнські святині; простежити частотність вживання та сутність слів Бог, Господь, Божий, Святий, сповідь, хрещення, причастя та ін.; дослідити ставлення до церковних канонів Шевченкових героїв.

Перший розділ монографії присвячено релігійному стилю Шевченкових творів. І. Огієнко зазначає, що «стиль - ие правдива душа поета... Стиль малюс Шевченка як глибокого філософа, істотно окраменого релігійністю» [Огієнко 2003: 170].

Дослідник вважає, що релігійний стиль Шевченкових творів не придуманий, не є поетичною окрасою, - це живий реалізм, без якого «описи були б мертві й чужі народові... Невіруючий ніколи б не створив такого стилю: 


\section{За святую Віру-Волю \\ розбійник не стане!..» [Огієнко 2003: 172].}

I. Огієнко вказує на наявність правдивих відомостей i фактів iз приватного життя Т. Шевченка, які ясно свідчать, що він усе життя був релігійною людиною, й намагається простежити витоки його побожності, серед яких перше місце надає родині, яка була глибоко віруючою. Акцент зроблено на пливові матері та діда: «Особливо Шевченкова мати, теплий малюнок якої неодноразово подано у творах... та дід, письменний, який любив читати по неділях Мінею - книгу, в якій описано життя святих $і$ подано їх за днями місяия» [Огієнко 2003: 174].

Другим чинником формування релігійних поглядів Т. Шевченка I. Огієнко вважає його навчання в дяків, адже саме на той період припадає його знайомство зі святими книгами: «Псалтиря знав мало не напам'ять. Кохався в Біблї і багато ї̈ читав...» [Огієнко 2003: 175]. Пізніше, вже будучи в зрілому віці, «любив перекладати поетичні біблійні книги, цебто Псалтиря та Пророків, які головно на нього впливали і змістом, і своєю поетичною формою» [Огієнко 2003: 175]. Третьою складовою релігійності Т. Шевченка було саме життя, наповнене стражданнями, зневірою, поневіряннями, які не зламали письменника. Митрополит подає цитату із листа Б. Залеського до А. Венжиновського про великий відчай Т. Шевченка, розпуку та бажання покінчити життя самогубством, але у цій ситуації подолати всі негаразди допомагає саме глибока віра в Бога.

Досліджуючи Шевченкову релігійність, І. Огієнко пропонує спогади доньки міщанки Кропивної, у яких тимчасово проживав Т. Шевченко, перебуваючи в Києві 1859 року. Вона розповідає, що «поет вставав о 4-ій годині, ...вмивався холодною водою, а потім молився» [Огієнко 2003: 176].

Вміщує монографічне дослідження розділ, у якому митрополит Іларіон досліджує лексеми Бог чи Господь, Богородиия чи Матір Божа. Дослідник зазначає, що в Шевченкових поезіях використано сталі вирази: Дай Боже, Слава Богу, Крий Боже, Сохрань Боже та ін., і подає приклади: «Нехай йому 
Бог поможе!...Та не дав мені Бог ані щастя, Ні долі...Та не дай, Господи, нікому, Як мені тепер старому...Прожив, слава Богу - підтоптався... В вікно подали Христа ради...».

Зосереджує увагу дослідник і на виразах «Боже милий» та «світ Божий» (О Боже милий, Боже великий!..I світа Божого не бачить...), зазначаючи, що до Бога Т. Шевченко добирає найніжніші епітети: милостивий, милосердний, єдиний, великий та ін. Окремо проаналізовано значення епітета святий, як «високопоказне Шевченкового релігійного стилю» [Огієнко 2003: 185], зокрема дослідник звернув увагу, що в поемі «Марія» слово «святий» ужито 34 рази (Святую доленьку Твою..., Свою головоньку святую..., Святії думоньки Твої ma ін.).

Звернення до Богородииі, Maтері Божої в Т. Шевченка також часті:

$$
\text { О Матер Божая! }
$$

Розкуй мою ти душу! [Огієнко 2003: 225].

Митрополит Іларіон доводить, що Т. Шевченко добре обізнаний із оповіданням про плач - сльози Богородиці, коли вона заступалася за Україну. Він подає приклад: «Не плакала б Матер Божа в Криму за Украйну...» [Огієнко 2003: 186].

Грунтовними $є$ дослідження про християнські святині, які потлумачено 3 погляду релігії, фольклору та самого поета: Небо - найвище, найсвітліше за все; Рай (благодать) - найкраще, святе, душевне; Природа - творіння Боже; Місящь i Зорi - слуги Божі; Хрест - велика помічна сила і оборона від злого, Клятва божіння; Хрещення і Сповідь - обов'язок кожного; Причастя - необхідність та ін.

Одним із найскладніших розділів, за словами I. Огієнка, є «Шевченкова моральна і релігійна наука», де доведено навчальну, моральну, виховну функції Шевченкових творів. Зокрема, зазначено, що «усі твори Шевченка - виразно навчальні, бо він науку твору ставив на перший план», «усі твори Шевченка моральні та виховні, бо він нагадує головну новозавітню заповідь: 
... Щоб навчились

Путями добрими ходить,

Святого Господа любить...

I брата милувать» [Огієнко 2003: 225].

Окремий розділ присвячено поемі «Марія», у якому закцентовано увагу на «цілях» написання («щоб, Святая сило всіх Святих, Пренепорочная, благая, поблагословила селянство до нового життя, яке уряд готує проектом 1861 року»), досліджено джерела твору: «для Шевченкової «Марії» головним джерелом був «Акафіст Пресвятої Богородиці»»; простежено історію написання.

I. Огієнко наголошує й на недоліках поеми: «Марія», як поема, багато недороблена - треба було б ще багато працювати над ії змістом, щоб надати їй величної святости і повноти. Шевченко спинився головно на Діві Марії і малює-описує головно іï...I то головно Марія як мати-селянка. А про Iсуса (якого він зве Пророком Ісаєю) дано дуже мало, а треба було б змалювати ширше його Образ. Особливо останні розділи «Марії» зовсім недороблені!» [Огієнко 2003: 255].

В окремому розділі митрополит проводить паралелі між «Акафістом Богородиці» та «Марією». Він зазначає, що «перед поемою поставлено епіграф п’ятого вітання Богородиці з 10-го ікоса: «Радуйся, Ти бо обновила єси зачатия студно» та вказує на обізнаність Шевченкову: «акафіст, як поетичну церковну форму, поет добре знав, знав його будову i наслідував його» [Огієнко 2003: 270].

Завершальний розділ монографічного дослідження названо ствердно «Шевченко був віруючий!». І. Огієнко робить висновок: «Шевченко був людиною щиро й глибоко релігійною, а його «нарікання» на Бога були випадковими і виходили виключно з його розпачу, в який він впадав через неймовірно тяжкий стан життя і всієї України, і свого власного» [Огієнко 2003: 274]. Митрополит заперечує атеїзм Т. Шевченка, наводячи аргументи, взяті із «Щоденника»: «О, як солодко, як невимовно солодко вірити в це 
прекрасне майбутнє! Я був би байдужий холодний атеїст, якби не вірив у цього прекрасного Бога, - в цю чарівну надію!» [Огієнко 2003: 274], спростовує думку «комуністичних дослідників, які натягують Шевченка на комуністабезбожника», критикує совєтські видання, що «переробляють тексти Шевченка на нерелігійні і написи 3 малої літери: бог, господь, дух святий, мати божа та ін.». Завершує І. Огієнко дослідження зверненням до всіх тих, хто спотворює творчість Т. Шевченка та не вірить в його глибоку релігійність, подаючи цитату із поезії «Холодний Яр»:

Дуріть себе, чужих людей,

Та не дуріть Бога! [Огієнко 2003: 280].

Отже, як бачимо, митрополит Іларіон зробив спробу глибокого аналізу творчості Тараса Шевченка в аспекті релігійності, що підтверджує його інтерес та добру обізнаність у набутку письменника, адже за його словами: «Щоб судити Шевченка, треба глибоко його зрозуміти, інакше наш суд буде неправдивий» [Огієнко 2003: 280].

\section{БІБЛІОГРАФІЯ}

Огієнко 2003 - Огієнко I. Тарас Шевченко /Упорядник, автор передмови і коментарів М. Тимошик. - К., 2003. - С. 164-280.

Степовик 2013 - Степовик Д. Наслідуючи Христа: Віруючий у Бога Тарас Шевченко. - К., 2013. - 480 с.

Шевченко 2009 - Шевченко Т. Кобзар. Повна ілюстрована збірка [Текст] / передм. І. Дзюби. - Харків, 2009. - 720 с. 